\title{
SENTRA UMKM MODE
}

\author{
Agatha Lavinia1), Martin Halim ${ }^{21}$ \\ 1)Program Studi S1 Arsitektur, Fakultas Teknik, Universitas Tarumanagara, agatha.lavinia@yahoo.com \\ 2) Program Studi S1 Arsitektur, Fakultas Teknik, Universitas Tarumanagara, martinhalim90@gmail.com
}

Masuk: 20-01-2021, revisi: 21-02-2021, diterima untuk diterbitkan: 26-03-2021

\begin{abstract}
Abstrak
Berhuni merupakan cara manusia untuk merespon perubahan yang ada, namun tidak semua manusia siap akan adanya perubahan tersebut. Manusia yang tidak siap beradaptasi dengan kecanggihan teknologi akan kalah bersaing dengan manusia yang siap memanfaatkan kemajuan teknologi yang ada. Demikian halnya dengan permasalahan yang terjadi di daerah Tanah Sereal, Tambora, Jakarta Barat. Tanah Sereal memiliki banyak permasalahan salah satunya adalah dikarenakan lokasi rumah produksi yang tersebar menyebabkan membatasi kesempatan pembeli menentukan rumah produksi yang ada. Selain dari itu, pandemi mempengaruhi tingkat penjualan konveksi di tanah sereal hingga menurun. Hal ini menyebabkan banyak pedagang beralih ke perdagangan online. Perdagangan online menimbulkan masalah baru bagi bara pembeli karena barang yang dibeli bersifat personal sehingga butuh dicoba. Dalam merespon kedua permasalahan tersebut dibutuhkan pengelompokan rumah produksi untuk memudahkan pembeli memilih penjual yang ada dan memberikan kesempatan bagi pembeli mencoba barang yang dibeli sehingga sentra UKM mode tercipta. Kajian teori yang dipilih berupa kajian mengenai terori dwelling menururt Chistian Norberg-Schulz, teori everydayness, pelatihan kerja, UMKM, dan sentra UMKM. Metode perancangan yang dilakukan menggunakan metode analisis-sintesis berdasarkan data kawasan dan pola kegiatan masyarakat di Tanah Sereal. Dengan adanya sentra UMKM mode diharapkan dapat menyelesaikan masalah tersebarnya rumah produksi, memberikan konektivitas antar pengunjung dengan rumah produksi sehingga dapat meningkatkan citra kawasan Tanah Sereal.
\end{abstract}

Kata kunci: Dwelling; Konveksi; Sentra UMKM Mode; Tanah Sereal

\begin{abstract}
Dwelling is a human respond for tha changes, but not all humans are ready for it. Humans who are not compatible enough will unable to compete with who are ready to take advantages for the changes especialy techologhy related. Likewise with the problem that accured in Tanah Sereal, Tambora, West Jakarta. Tanah Sereal has has many problem, one of wich isdie to the scattered location of the production house conduce limited opportunity for the buyers to determine existing production house. Apart from that, the pandemic effect the sales rate to decrease in Tanah Sereal. This leads manya production houses to change to online trading. Online Trading creates new problem for buyers because of the items are personalized they need to be tried on. To respond of these problem, it is necessary to agglomerate the production houses to make it easier for the prospective buyer to choose existing sellers. It also provide opportunities for buyers to try the purchased item so that fashion MSME center are creates. The choses theory is in the form of study of dwelling according to Christian Norbrg-Schulz, job training, MSMEs, and MSME centers. Desain method that is used is analysis-synthesis method based on region data and community activity patterns in Tanah Sereal. With fashion MSME center, it is hoped to solve the distribution location of production houses, provide conectivitu between visitors and production hoises to improve the image of Tanah Sereal.
\end{abstract}

Keywords: Convection; Dwelling; Fashion MSME Center; Tanah Sereal 


\section{PENDAHULUAN}

\section{Latar Belakang}

Tanah sereal merupakan daerah produksi konveksi yang memproduksi busana siap pakai. Penduduk yang mayoritas merupakan pedagang konveksi dan buruh penjahit konveksi sangat menggantungkan kehidupannya pada penjualan konveksi di Tanah Sereal. Skala produksi konveksi saat ini adalah skala rumahan dengan cara produksi terbagi menjadi beberapa bagian yaitu: pembuatan pola, pemotongan, penjahitan, dan sablon. Kekurangan dari cara kerja seperti ini adalah pekerja hanya menguasai satu bidang keahlian sehingga tidak dapat membuat pakaian secara utuh. Lokasi rumah produksi konveksi di Tanah Sereal yang tersebar membatasi kemudahan pembeli untuk membandingkan satu rumah produksi dengan rumah produksi lainnya. Saat ini karena adanya pembatasan aktivitas mempengaruhi hasil produksi konveksi di Tanah Sereal hingga menurun. Dalam merespon permasalahan tersebut banyak rumah produksi yang mengalihkan cara berjualan dengan membuka bisnis online. Namun dikarenakan barang yang dijual personal diperlukan pengenalan produk yang lebih sehingga pembeli dapat yakin membeli barang tersebut.

Dalam pembelian barang personal seperti celana, pakaian dan sepatu masyarakat Indonesia masih butuh mencoba dan merasakan barang tersebut sehingga penjualan barang produksi tidak hanya berfokus pada cara online tetapi juga offline. Dengan menggabungkan kedua cara tersebut dapat menciptakan pengalaman berbelanja baru yang terintegrasi antara online maupun offline. Dengan mengelompokan rumah produksi yang tersebar, dapat meningkatkan kualitas karya rumah produksi melalui kompetisi dan mempermudah pembeli dalam memilih rumah produksi yang diinginkan. Dalam mewujudkan hal tersebut tidak hanya cara berbelanja baru yang perlu diusulkan tetapi juga pengelompokan rumah produksi. Pengelompokan rumah produksi kemudian dianggap perlu demi meningkatkan konektifitas antar penjual dan pembeli guna meningkatkan penjualan dan citra kawasan Tanah Sereal.

\section{Rumusan Masalah}

Rumusan masalah yang ingin dijawab melalui proyek ini adalah bagaimana dengan mengelompokan rumah produksi di Tanah Sereal dapat meningkatkan kualitas karya dan pemasaran pada hingga dapat memperkuat citra kawasan yang ada

\section{Tujuan}

Tujuan dari proyek ini adalah untuk menciptakan wadah bagi masyarakat untuk mengembangkan potensi yang ada sesuai dengan kebutuhan pasar setempat sehingga dapat meningkatkan taraf hidup di kawasan Tanah Sereal.

\section{KAJIAN LITERATUR}

\section{Dwelling}

Menurut Chistian Norberg-Schulz (1985:135) dalam berhuni terbentuk 3 buah ruang yaitu ruang personal dimana manusia bisa mengembangkan dirinya, pengaplikasian pada desain berupa ruang pelatihan. Ruang untuk bertemu dengan orang lain dan bersifat sebagai ruang untuk pertukaran sebuah ide, pengaplikasian pada desain berupa ruang komunal. Dan ruang terakhir merupakan ruang public dimana ketika manusia berada di ruang tersebut harus dapat menerima nilai-nilai dalam masyarakat dan menyetujui kesepakatan yang telah ada.

Berdasarkan konsep di atas dapat disimpulkan bahwa berhuni merupakan respon kita terhadap perubahan yang ada. Respon terhadap perubahan tersebut dapat berupa timbulnya ruang-ruang dalam lingkungan bermasyarakat maupun pribadi guna mempertahankan sifat dasar manusia dalam mempertahankan eksistensinya. 


\section{Everydayness}

Everydayness merupakan upaya untuk menciptakan heterogenitas kawasan guna memperkuat karakteristik kawasan agar tidak beralih fungsi. Peralihan fungsi ini tercipta karena adanya demand sehingga tercipta aktivitas baru yang mengubah fungsi ruang yang ada. Peralihan fungsi tersebut menciptakan heterogenitas ruang pengukung dan dapat memperkuat karakter domestisitas kawasan. Perkembangan teknologi saat ini menghilangkan heterogenitas kawasan yang tercipta yang merupakan suatu ancaman tersendiri terhadap pemaknaan everydayness. Hal ini dapat terlihat melalui jenis fungsi dari sentra umkm mode yang memperkuat karakter domestic kawasan yaitu sebagai tempat produksi konveksi. Tetapi heterogenitas juga tetap dipertahankan dengan memasukkan fungsi pendukung berupa pelatihan menjahit dan fasilitas pendukung bagi para perancang dan penjahit untuk berkembang.

\section{Pelatihan Kerja}

Pelatihan kerja merupakan kegiatan untuk meningkatkan kompetensi kerja pada tingkat keterampilan dan keahlian tertentu sesuai kebutuhan pekerjaan. Menurut Carrell dan Kuzmits (1982:282) mendefinisikan pelatihan sebagai proses sistematis dimana karyawan mempelajari pengetahuan (knowledge), ketrampilan (skill), kemampuan (ability) atau perilaku terhadap tujuan pribadi dan organisasi. Pada sentra UMKM Mode jenis pelatihan kerja yang diterapkan berupa peningkatan keterampilan peserta didik mengenai teknik menjahit dan pembuatan baju melalui pemberian informasi secara teori maupun praktik.

\section{UMKM}

Badan Pusat Statistik (BPS) memberikan definisi UKM berdasarkan kuantitas tenaga kerja. Usaha kecil merupakan entitas usaha yangmemiliki jumlah tenaga kerja 5 sampai dengan 19 orang, sedangkan usaha menengah merupakan entitias usaha yang memiliki tenaga kerja 20 sampai dengan 99 orang. Jenis usaha yang terdapat pada sentra UMKM Mode adalah produksi konveksi dengan banyak tenaga kerja sebanyak 5 hingga 20 orang

\section{Sentra UMKM}

Dalam Surat Keputusan Menteri Negara Koperasi dan UKM No: 32/Kep/M.KUKM/IV/2002, tanggal 17 April 2002 Sentra didefinisikan sebagai pusat kegiatan di kawasan/lokasi tertentu dimana terdapat UKM yang menggunakan bahan baku/sarana yang sama, menghasilkan produk yang sama/sejenis serta memiliki prospek untuk dikembangkan menjadi klaster. Sedangkan klaster merupakan pusat kegiatan UKM pada sentra yang sudah berkembang. Hal ini terlihat melalui munculkanya spesifikasi dan spesialisasi proses produksi pada masingmasing UKM. Hal ini menyebabkan kegiatan ekonomi saling terkait dan mendukung. Jika dikorealsikan dengan proyek senta UMKM mode bertujuan mengumpulkan rumah produksi konveksi yang menggunakan bahan baku, sarana, dan menghasilkan produk yang sejenis berupa pakaian yang terolah agar dapat saling berkompetisi meningkatkan hasil kerja dan memudahkan pembeli untuk mencari rumah produksi yang diinginkan.

\section{METODE}

Pada penelitian ini metode yang dipakai adalah metode analisis-sintesis yang meliputi pengumpulan data (input), analisis (proses), dan sintesis (output). Data yang dikumpulkan berupa informasi mengenai permasalahan kawasan, kebutuhan masyarakat, polah hidup, komunitas yang ada serta citra kawasan yang terbentuk. Analisis yang dihasilkan berdasarkan pada dokumen, karya ilmiah, maupun buku megenai fenomena makloon dan informasi mengenai Tanah Sereal. Dari informasi yang dikumpulkan maka diketahui bahwa Tanah Sereal memiliki fenomena rumah produksi yang tersebar dan cara peoduksi yang terpisah sehingga membatasi kemampuan penjahit yang ada. Sintesa yang dihasilkan adalah dengan 
menciptakan pola desain yang dapat menggambarkan citra kawasan sebagai tempat produksi pakaian mode dan program yang dihadirkan dapat mendukung pengelompokan rumah produksi yang ada serta meningkatkan kemampuan bagi masyarakat sekitar.

Proses desain menggunakan metode kontekstual yang diperkenalkan oleh Anthony C Anthoniades melalui bukunya yang berjudul poetic of Architecture. Melalui bukunya, Anthony menceritakan bahwa proses desain dengan metode kontekstual dapat mengacu pada desain yang merefleksikan site dari lingkungan, kondisi bangunan sekitar, masyarakat, budaya, dan material didaerah setempat. Pada proses desain sentra UMKM kontesktual yang dipilih mengacu pada kebudayaan dan pola kehidupan masyarakat di Tanah Sereal.

\section{DISKUSI DAN HASIL}

Proyek ini dinamakan sebagai sentra UMKM mode. Sesuai dengan namanya, proyek ini terbentuk guna mengelompokan rumah produksi yang tersebar di Tanah Sereal. Jenis aktivitas yang diwadahi berupa pelatihan, perdagangan dan kegiatan pendukung berupa communal place bagi masyarakat di Tanah Sereal.

Tanah Sereal merupakan salah satu kelurahan yang terletak di kecamatan Tambora, Jakarta Barat. Tanah sereal dikelilingi oleh daerah perdagangan, hal ini terlihat melalui lokasi geografis tanah sereal yang berada di antara kawasan Gajah Mada pada bagian timur, Jembatan Lima pada bagian Utara, dan Duri pada bagian barat. Dikarenakan dikelilingi oleh pusat perdagangan maka kawasan tanah sereal memiliki potensi perdagangan yang tinggi.

Secara lokasi, Tanah Sereal memiliki bentuk yang memanjang, tetapi tapak yang terpilih berada di bagian selatan dikarenakan pada bagian selatan memiliki potensi perdagangan yang tinggi karena bersebelahan dengan daerah Gajah Mada. Tapak yang terpilih memiliki potensi perdagangan yang baik karena terdapat Gajah Mada Plaza pada bagian timur dengan jarak 1 $\mathrm{km}$ dari tapak, terdapat wilayah komersil seperti minimarket dan bank, terdapat pula gedung pelayanan masyarakat seperti gedung pemadam kebakaran serta permukiman penduduk pada bagian selatan tapak, terdapat pasar Kampung Duri dengan jarak $600 \mathrm{~m}$ pada bagian barat tapak dan pada bagian utara merupakan daerah hunian.

Tapak berada di depan jalan Kiai Haji Zainul Arifin yang merupakan jalan kolektor dan memiliki arah kendaraan dari kiri ke kanan serta pada bagian belakang tapak terdapat rencana jalan baru. Ketinggian bangunan lingkungan sekeliling tapak berkisar antara 2 sampai dengan 4 lantai dan maksimal ketinggian adalah 4 lantai oleh karena itu ketinggian bangunan proyek adalah 4 lantai untuk memaksimalkan luasan yang ada. Lingkungan di sekeliling tapak berupa zona hijau yang berada pada samping kiri tapak, perdagangan pada bagian kanan tapak dan hunian pada bagian belakang tapak. 


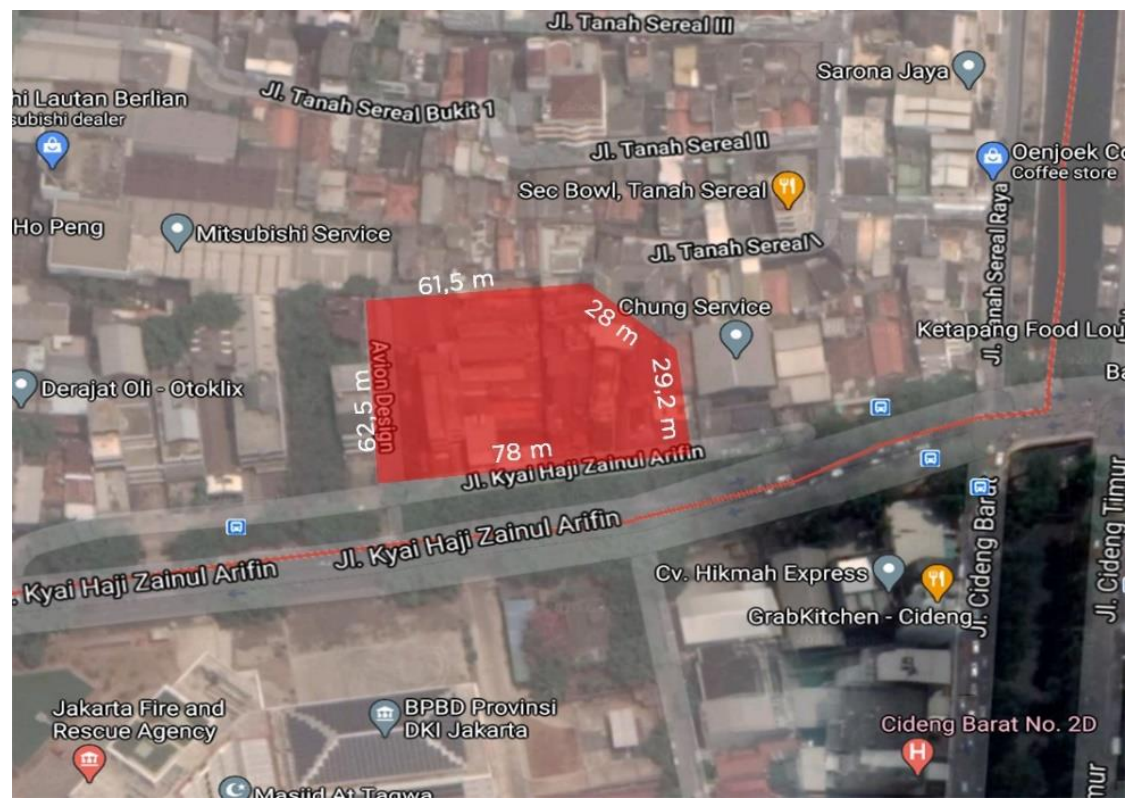

Gambar 1. Tapak Terpilih

Sumber: Google map, diolah oleh penulis

$\begin{array}{lll}\text { Peruntukan lahan } & : & \text { Perkantoran (K1) } \\ \text { Luas } & : & 4,530 \mathrm{~m}^{2} \\ \text { KDB } & : & 2,718 \mathrm{~m}^{2} \\ \text { KLB } & : & 10,872 \mathrm{~m}^{2} \\ \text { KB } & : & 4 \\ \text { KDH } & : & 1,359 \mathrm{~m}^{2} \\ \text { Alamat Tapak } & : & \text { Jl. Tanah Sereal Raya no.2, Tambora. }\end{array}$

Ide dasar dari sentra UMKM adalah dengan menggabungkan kegiatan berbelanja dengan teknologi dan komunitas penjahit yang ada. Program yang dihadirkan berupa area berbelanja, area komunal dan area pelatihan. Targetnya adalah start up, shopper dan masyarakat umum. Bentuk keruangan yang tercipta adalah interconnected communal, integrated, system dan ecological place. Pada interconnected komunal, ruang komunal yang tercipta tersebar tetapi terintegrasi ke plaza. Ruang komunal yang tercipta memiliki karkater ruang yang fleksibel sesuai kebutuhan yang ada. Seperti area gallery karya dapat berubah menjadi panggung fashion show. Integrated system dimaksudkan menggunakan system yang terintegrasi antara teknologi online dan offline Penggambaran pada desian berupa pola sirkulasi yang terhubung pada satu tempat sehingga memiliki pola sirkulasi yang terpusat. Ecological place dimaksudkan ruang yang tercipta memiliki timbal balik positif dengan lingkungan di sekitarnya. Penerapannya berupa open air building untuk menciptakan interaksi antara pengguna dan lingkungan sekitar. 


\section{Penerapan metode kontekstual pada desain}

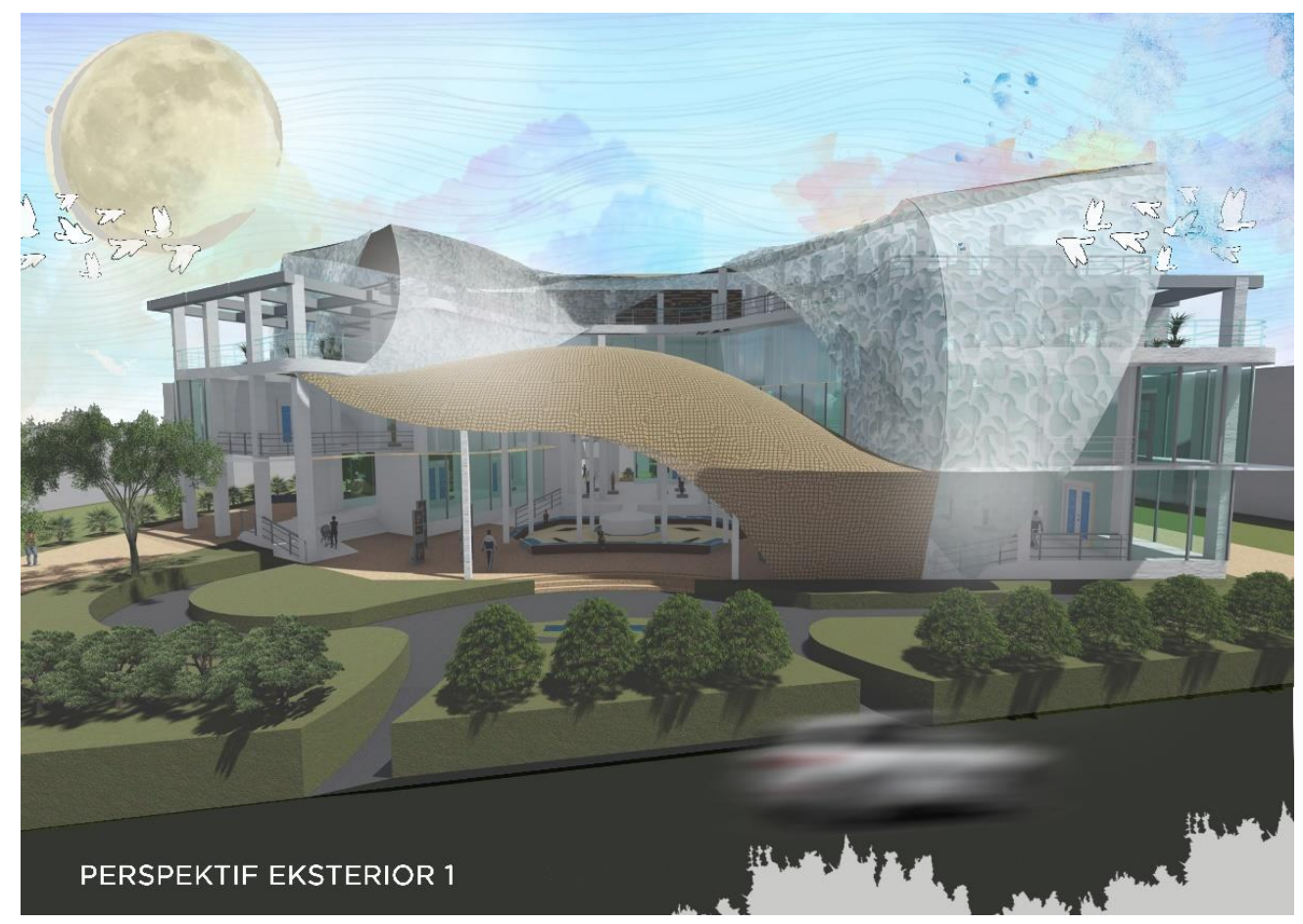

Gambar 2. Perspektif Eksterior 1

Sumber: Penulis, 2020

Façade menggunakan pola melengkung mengumpamakan bentuk kain jatuh. Bentuk ini merepresentasikan fungsi bangunan sebagai sentra UMKM mode. Pemilihan bahan menggunakan bahan transparan dengan memiliki motif oval yang bergabung menjadi satu menggambarkan konektivitas antar 2 fungsi utama yaitu sebagai tempat berjualan dan pelatihan yang digabungkan melalui sebuah komunitas mode.

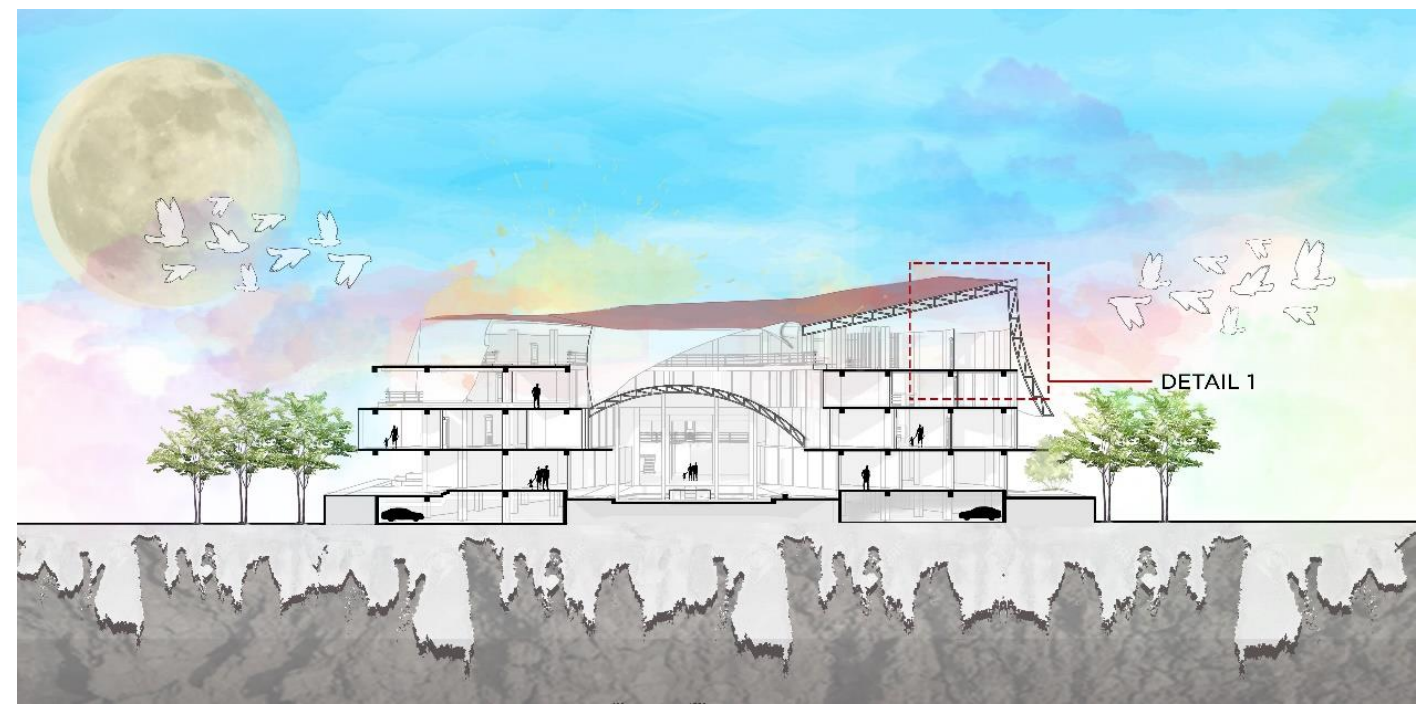

Gambar 3. Potongan Perspektif

Sumber: Penulis, 2020

Bentuk bangunan mengelilingi tapak dengan adanya atrium pada bagian tengah, atrium tersebut merepresentasikan fungsi komunitas sebagai penghubung dari berbagai kegiatan di sentra UMKM tersebut. Atrium dapat difungsikan sebagai tempat pentas maupun tempat duduk bagi para pengunjung beristirahat maupun menikmati penampilan yang ada. 


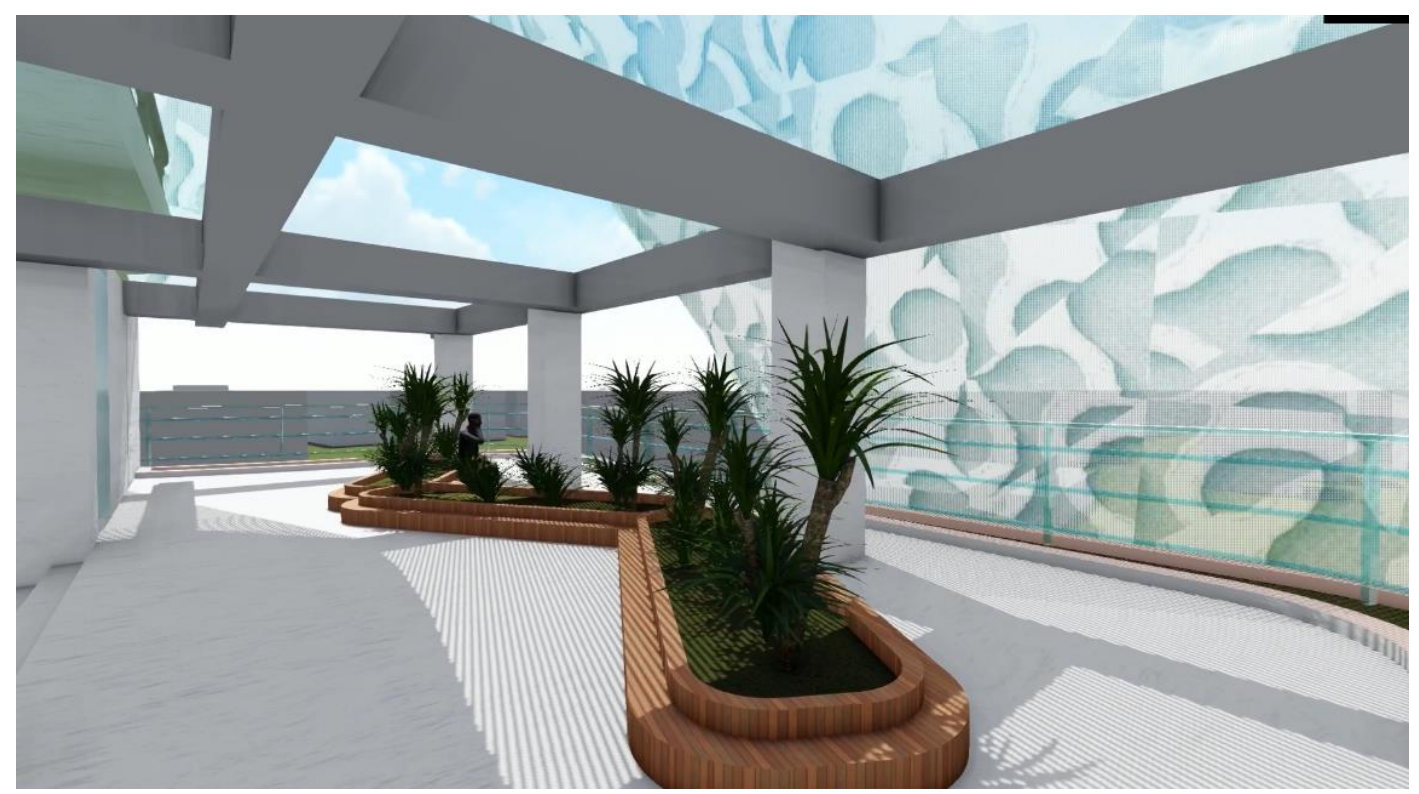

Gambar 4. Area Istirahat Pekerja Sumber: Penulis, 2020

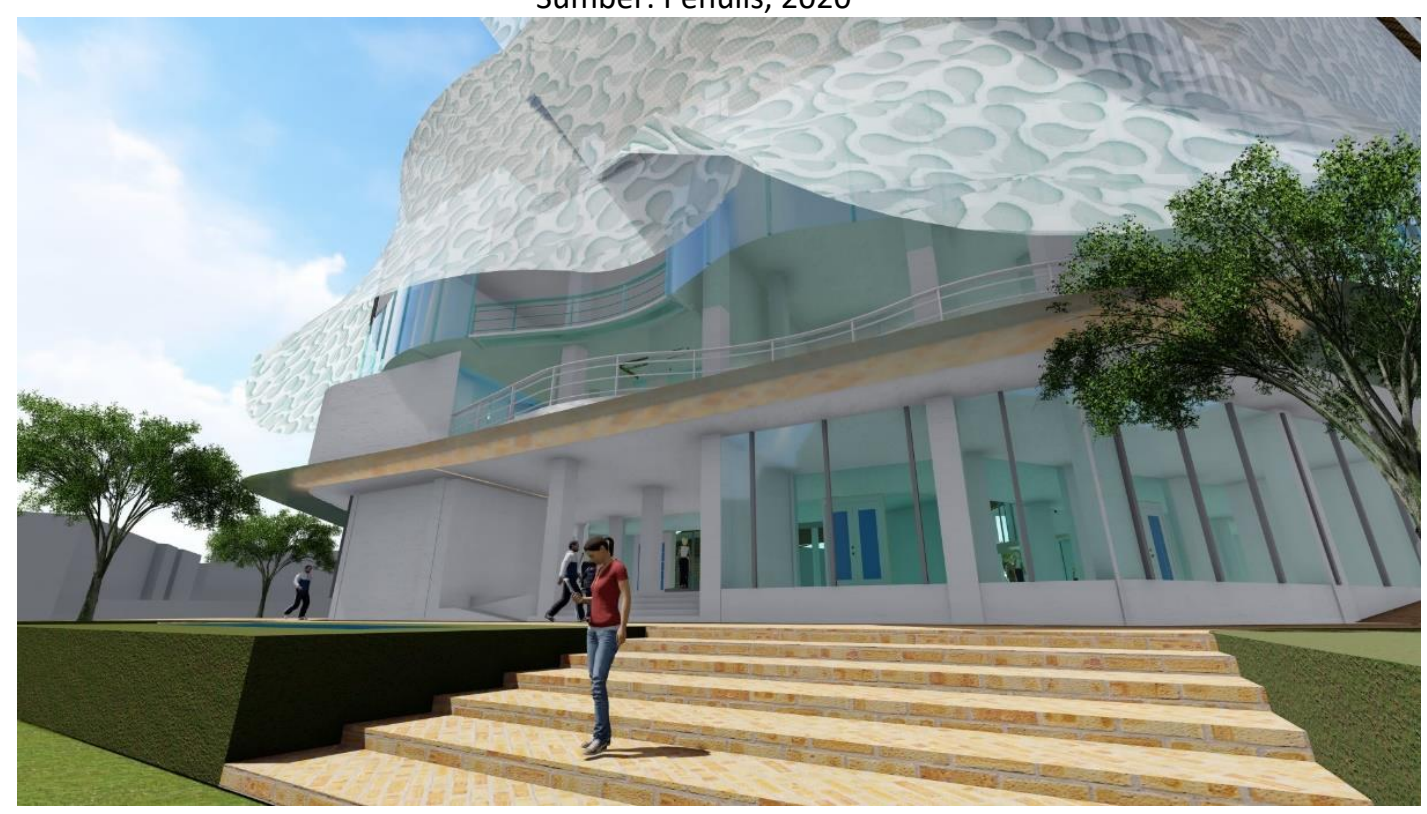

Gambar 5. Akses Masuk Pedestrian

Sumber: Penulis, 2020

Desain keruangan yang dihasilkan memiliki karakter terbuka memperhatikan bahwa lokasi tapak di tanah sereal dan juga target proyek merupakan masyarakat menengah bawah hingga menengah sehingga dipilih desain yang tidak hanya dapat merepresentasikan kebutuhan masyarakat tersebut tetapi juga bentuk bangunan yang merespon keadaan lingkungan yang ada. 


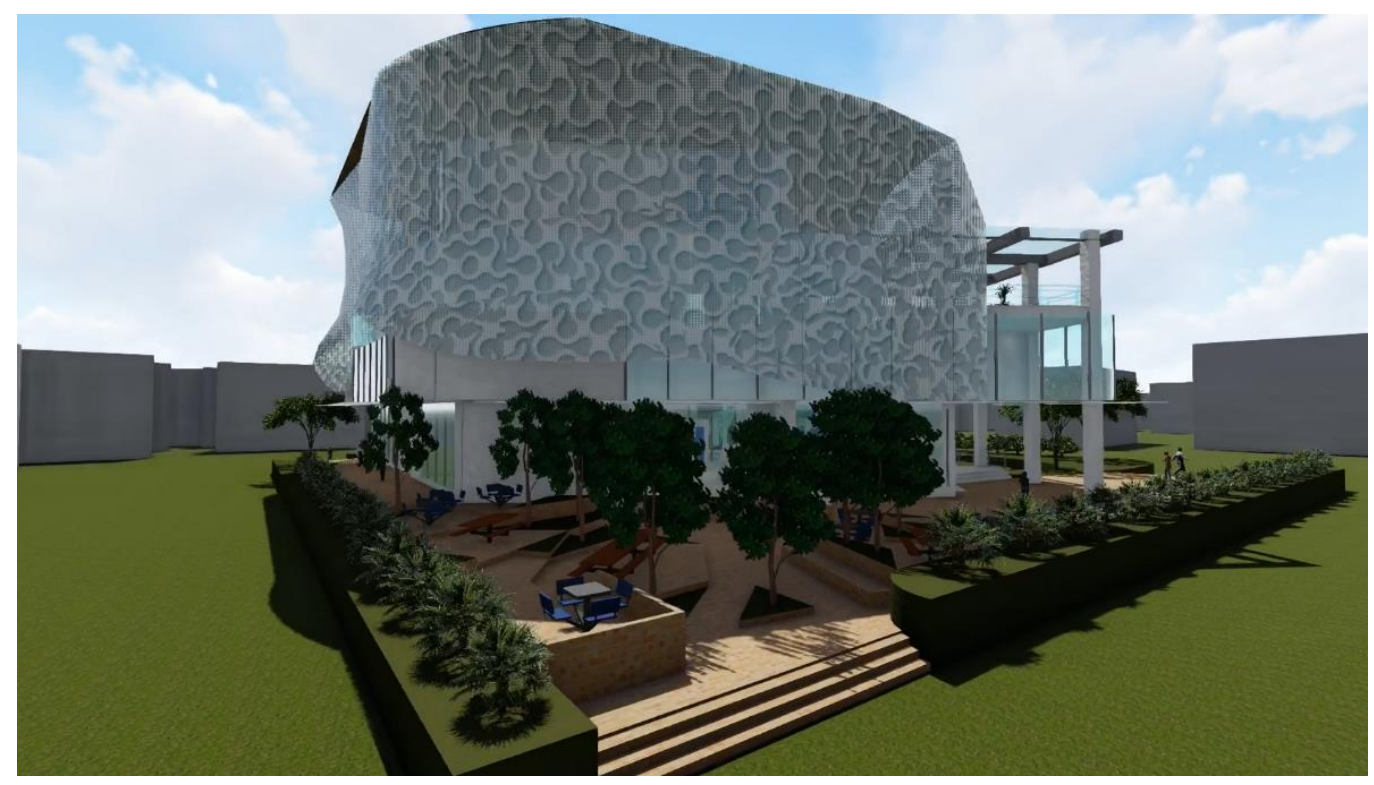

Gambar 6. Area Istirahat Outdoor

Sumber: Penulis, 2020

Merespon lokasi tapak yang bersebelahan dengan zona hijau, penulis memanfaatkan zona yang bersinggungan dengan ruang hijau menjadi tempat beristirahat pekerja yang dapat diakses pula oleh pengunjung. Area istirahat tersebut memiliki konektivitas yang tinggi dengan jalur masuk pedestrian yang berada di samping dan belakang tapak.

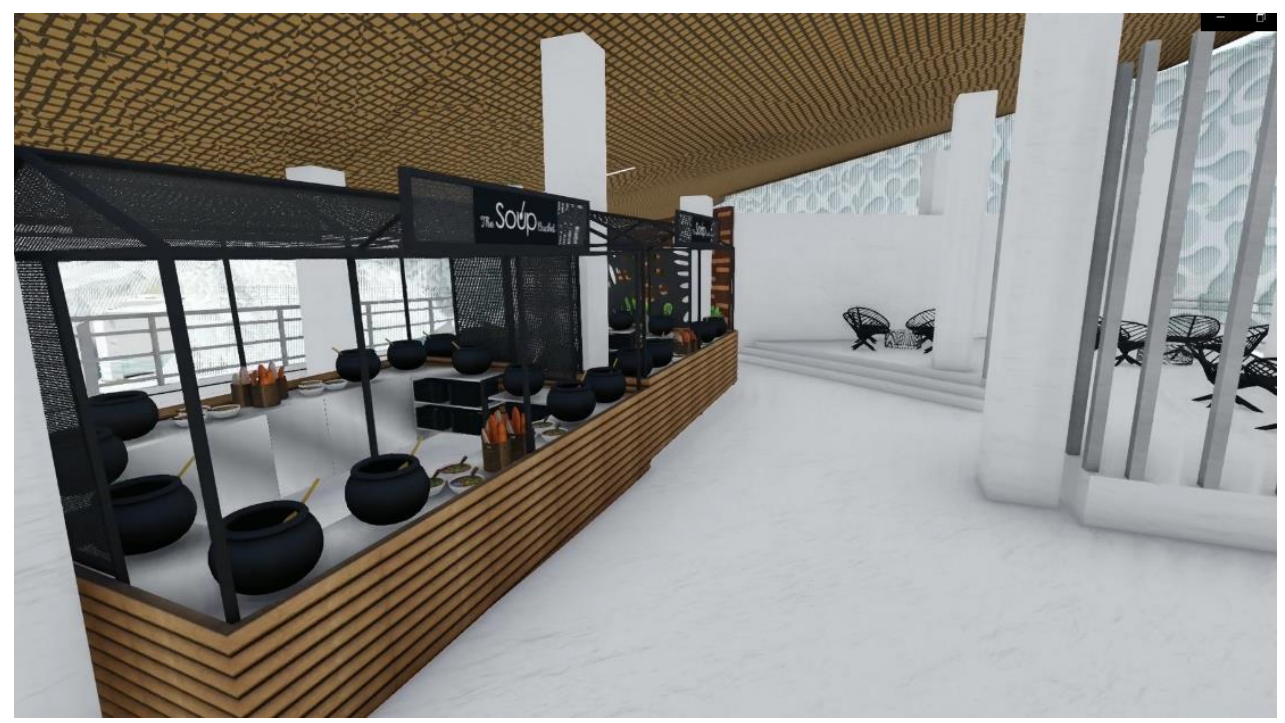

Gambar 7. Area Retail Makanan

Sumber: Penulis, 2020

Untuk mendukung fungsi retail dan pelatihan, penulis menambahkan fungsi area makan, area tersebut ditempatkan pada lantai paling atas bangunan guna menyebarkan titik keramaian pada setiap lantai. Dengan hal tersebut, diharapkan setiap lantai dapat menjadi hidup dan dapat memutar ekonomi pada bangunan ini. 


\section{KESIMPULAN}

Melalui fenomena tersebarnya rumah produksi di Tanah Sereal, tantangan yang hadir merupakan bagaimana menyediakan wadah yang dapat mendukung perkembangan rumah produksi yang ada dan bagaimana menhadirkan program yang dapat mengembangkan kualitas kerja penjahit. Cara penyelesaiannya berupa menghadirkan fungsi pelatihan bagi para penjahit dan membantu pemasaran rumah produksi melalui information board yang disediakan pada tiap lantai. Selain menggunakan cara digital, dengan adanya sentra UMKM akan memungkinkan komunitas tertentu untuk mengadakan acara di Tanah Sereal. Dengan adanya kemungkinan tersebut maka rumah produksi di sentra UMKM juga akan semakin dikenal. Bentuk arsitektur yang terbentuk dekat kaitannya dengan komunitas penjahit, rumah produksi, dan komunitas mode sehingga banyak disediakan ruang-ruang yang dapat memungkinkan adanya interaksi antara kebutuhan komunitas dengan lingkungan dengan sekitarnya.

\section{REFERENSI}

BPS. (2021, Januari 14). Konsep Usaha Kecil dan Menengah. Retrieved from Badan Pusat Statistik: https://www.bps.go.id/Subjek/view/id/35

Breeder, B. (2015, Agustus 16). Bangkok Fashion Hub. Retrieved from Bee Breeder: http://www.beebreeder.com

Harjoko, T. Y. (2019, Oktober 9). Dwelling and Settling (Tinggal dan Bermukim). Retrieved from UI Arch: http://www.uiarch.net

Khan, M. (2013, Desember 23). Blog Piece: Michel de Certeau's The Practice of Everyday Life. Retrieved from Transnational Everyday Life:http://www.transnationaleverydaylife.com

Kuzmits, F. E., \& Carrel, M. R. (1982). Personel Manajement of Human Resources. Ohio: Charles E Memil Publishing Company.

LinovHR. (2019, November 25). 7 Pengertian Sumber Daya Manusia Menurut Para Ahli. Retrieved from Linov HR: http://www.linovHR.com

Marlina, R. (2019). Kontekstual dalam Arsitektur. Jakarta: Verdant.id.

Menengah, M. N. (2002). Peraturan Menteri Negara Koperasi dan Usaha Kecil dan Menengah. Jakarta: Menteri Negara.

Norberg-Schulz, C. (1985). The Concept of Dwelling: on the way to figurative architecture. New York : Rizzoli

Space, L. (2020, Maret 1). 7 Pengertian Sumber Daya Manusia Menurut Para Ahli. Retrieved from Lano Space: http://www.lanospace.com 
